revista docência do ensino

v o I $\mathrm{u} \mathrm{m} 11$

\title{
SECTION: ARTICLES
}

\section{Women teaching Physics in higher education at two federal universities in Brazill}

\author{
Marcel de Almeida Freitas ${ }^{2}$, Adla Betsaida Martins Teixeira ${ }^{3}$, \\ Denise Bianca Maduro Silva ${ }^{4}$
}

\section{ABSTRACT}

The article is part of a qualitative study on gender relations in Physics courses of higher education. The study was conducted between 2014 and 2017, aiming to discuss experiences from women regarding the teaching career in Physics. Specifically in this article, the issues under discussion are related to the professional experiences of female academics at two federal institutions of teaching and research in Brazil: Federal University of Minas Gerais, in Belo Horizonte, and Federal University of Rio de Janeiro, in Rio de Janeiro. The research used semi-structured individual interviews. Male and female researches - professors and heads of departments - were interviewed; however, the article focuses on 11 female academics. Data show that the behavior of professors varies from concealing the femininity to avoid harassment, to supporting and encouraging female students, especially those who are discriminated by male scientists. Also, a tacit devaluation of teaching degrees in comparison to bachelor degrees was observed.

Keywords: Gender relations. Women in higher education. Physics teaching.

How to cite this document - ABNT

FREITAS, Marcel de Almeida; TEIXEIRA, Adla Betsaida Martins; SILVA, Denise Bianca Maduro. Women teaching physics in higher education at two federal universities in Brazil. Revista Docência do Ensino Superior, Belo Horizonte, v. 11, e024894, p. 1-18, 2021. DOI: https://doi.org/10.35699/2237-5864.2021.24894.
Received on: $27 / 08 / 2020$

Approved on: 30/01/2021 Published on: 25/06/2021

\footnotetext{
${ }^{1}$ The authors were responsible for translating this article into English.

${ }^{2}$ Universidade do Estado de Minas Gerais (UEMG), Divinópolis, MG, Brasil. ORCID ID: http://orcid.org/0000-0003-4928-2136. Email: marcel.fae.ufmg@gmail.com

${ }^{3}$ Universidade Federal de Minas Gerais (UFMG), Belo Horizonte, MG, Brasil. ORCID ID: http://orcid.org/0000-0001-5400-470X. Email: adlaufmg@gmail.com

${ }^{4}$ Universidade Federal de Minas Gerais (UFMG), Belo Horizonte, MG, Brasil. ORCID ID: http://orcid.org/0000-0002-4909-1850. Email: denisebianca@reitoria.ufmg.br
} 


\section{Mujeres docentes en cursos superiores de Física en dos universidades federales en Brasil}

\section{RESUMEN}

El artículo es parte de una investigación cualitativa sobre relaciones de género en cursos superiores de Física. La investigación se realizó entre 2014 y 2017, con el objetivo de discutir experiencias sobre la carrera docente en Física. Específicamente en este artículo, los temas en discusión son las experiencias profesionales de académicas en dos instituciones federales de enseñanza e investigación: Universidad Federal de Minas Gerais (Belo Horizonte) y Universidad Federal do Rio de Janeiro (Rio de Janeiro). La investigación utilizó entrevistas semiestructuradas individuales. Profesionales masculinos y femeninos fueron entrevistados (profesores y jefes de departamento), sin embargo, el artículo se centra en 11 académicas. Los datos muestran que el comportamiento de las investigadoras varía de encubrir la feminidad para evitar el acoso, al apoyo y estímulo (en relación a las alumnas, especialmente aquellas que son discriminadas por científicos hombres). También se observó un desprecio tácito del magisterio en comparación al bachillerato.

Palabras clave: Relaciones de género. Enseñanza de Física en la educación superior. Mujeres en la Física.

\section{Mulheres docentes em cursos superiores de Física em duas universidades federais no Brasil}

\section{RESUMO}

O artigo é parte de uma pesquisa qualitativa sobre relações de gênero em cursos superiores de Física. O estudo foi realizado entre 2014 e 2017, buscando discutir experiências de mulheres concernentes à carreira docente na Física. Especificamente neste texto, os temas discutidos se relacionam às experiências profissionais de acadêmicas em duas instituições federais de ensino e pesquisa no Brasil: Universidade Federal de Minas Gerais (Belo Horizonte) e Universidade Federal do Rio de Janeiro (Rio de Janeiro). O estudo utilizou entrevistas individuais semiestruturadas. Foram entrevistados tanto homens quanto mulheres (professores e chefes de departamento), porém, o artigo enfoca 11 acadêmicas. Os dados mostram que o comportamento das acadêmicas varia de escamotear a feminilidade para evitar o assédio ao apoio e incentivo (em relação às estudantes, sobretudo aquelas que foram discriminadas por cientistas do sexo masculino). Também foi observada a desvalorização tácita da licenciatura em comparação ao bacharelado.

Palavras-chave: Relações de gênero. Mulheres no ensino superior. Docência de Física. 


\section{INTRODUCTION}

Numbers from the study entitled Trajetória das Mulheres na Educação Superior Brasileira (Women's Trajectory in Brazilian Higher Education), from 1991 to 2004, show a significant growth in the number of women in university education, surpassing the number of men at this level (INEP, 2005). Similarly, the rate of graduates in tertiary education has increased among women across the country (52\% in 2012), with the male rate being reduced $(42 \%$ in 2012), as Barreto (2014) indicates. The fact that Brazilian women excel numerically in schooling (entry and completion) at all levels of education (primary, secondary and higher education) has been understood as the main factor related to the growth of their participation in higher education teaching between 2000 and 2013.

In spite of the significant increase in academic qualification rates, Brazilian women still present lower production of scientific knowledge compared to men (MELO; LASTRES; MARQUES, 2004; LETA, 2014; SVARCZ, 2017) and still do not hold the positions of greater power and/or prestige in higher education institutions. In addition to that, segregation of women in Arts, Humanities, Social sciences and Health areas still exist, and the number of women is smaller in the areas of exact and earth sciences, which keep them in positions of lower salary, prestige and power (RISTOFF, 2006).

In fact, the women absence in hard sciences occurs worldwide and has worried researchers and feminist activists in many countries (THERRIEN, 1998; LOMBARDI, 2017; BENÍCIO, 2019). This is partially due to a fragile formation in the self-perception of women in the professional world, which can be influenced by a process that comes from the early years of socialization in the family and in the initial education.

For that, models, concrete examples ${ }^{5}$, practical activities, passionate teachers, and enthusiastic support are needed. It takes more female teachers to serve as models to encourage more young girls to choose physics as a career. With a little perseverance, [...] girls will no longer see physics as a men's field and will come to regard it as a concrete platform on which to build their future (GARG; AGRELLO, 2009, p. 1305, our translation).

In this sense, the fact that more women attend higher education, despite being a conquest, does not guarantee them the conditions to achieve professional success, nor does it break with sexual segregation inside areas of knowledge (FREITAS, 2018). Discrimination continues even if these women start not to be subject to social and economic stigmas and barriers, entering courses traditionally occupied by men.

What happens to women who break with social expectations/traditions and attend these courses? Are they ordinary women or have they become unusual in order to survive in these

\footnotetext{
${ }^{5}$ A great current example is the professor Andrea Ghez, Nobel Prize in Physics 2020.
} 
spaces? What could be done so that more and different women feel comfortable in these courses, with the possibility of being in these places? Based on these questions, this study seeks to understand the trajectories of women in Physics, trying to contextualize pedagogical practices, initiate institutional policies and inclusion policies for women in scientific and technological careers.

The research was carried out from semi-structured individual interviews with men and women (professors and heads of departments) of two Physics courses at two federal universities in the southeast of Brazil: Federal University of Minas Gerais (UFMG) and Federal University of Rio de Janeiro (UFRJ). The study covered broader aspects of the interviewees, such as school, family and professional experiences; however, due to the scope of this scientific journal, this article will discuss aspects related to the processes of professional behavior and insertion of female academics in the teaching of Physics. For this text's purpose, statements regarding the teaching activities were selected, identifying the discourses conflicts, resistance, strategies and values that influence the professional practices and the interactions with peers of eleven women Physics teachers in higher education that were interviewed.

Regarding research results, this text discusses gender exclusions and discriminations in higher education organizations in relation to women as well as the historical, economic and symbolic devaluation of the teaching degree ${ }^{6}$ in Brazil (VIANNA, 2002). The analyses are based on the notion of social conditions of production, as this notion is thought in the area of Discourse Analysis. As Carabine (2001) defines, discourse analysis is an approach that investigate the use of language functions and its aspects in different speech groups to understand patterns either in spoken or written forms, as well as their correlation with the societies in general and/or with small contexts.

In teaching, the relevance of these analyses is associated with the possibilities that the discourses produced in these socio-historical conditions have to help us understand the social imaginary of students and teachers (NASCIMENTO; PLANTIN; VIEIRA, 2008), as well as the micropolitics in which the real subjects are immersed. Institutional micropolitics is understood as relations of power, values, practices, symbols and organizational cultures that determine, define, limit or favor the professional histories of men and women; in short, the possibilities or obstacles of the concrete individuals in public or private organizations (BALL, 1989).

\footnotetext{
${ }^{6}$ In this article, we option by Teaching Degree, though unusual in English, especially American English. In Brazil, when starting college, students must decide which path to follow in their undergraduate studies. Usually, there are two options available: the bachelor's degree (which is focused on researching) or what is called "teaching degree" (which focuses mainly on teaching). This distinction is important for this article, even though it is clear for the authors that it does not happen the same way in United States, Canada or in most European countries.
} 
In this study, we understand gender discriminations as a social strategy to justify power and exploitation of some groups over others. It is certainly a historical and cultural construction that has been efficiently used to keep inequalities between women and men (SCOTT, 2012; MIRANDA; SCHIMANSKI, 2014). Therefore, certain norms, values and gestures have been associated with masculinity and femininity to implement hierarchy between men and women. Thus, it urges to denaturalize identities and roles dictated as masculine or feminine. Gender has a relational characteristic (CISNE, 2015).

Therefore, misogyny is defined in this article as hatred of women in general, expressed as repulsion, intolerance, discrimination and/or entrenched prejudice, aiding to legitimate women's oppression in patriarchal societies and cultural systems (SUMMERS, 2013). However, occasionally women can also adopt misogynistic beliefs, through self-hatred or self-objectification, what is very different from a low self-esteem in relation to oneself (knowledge, abilities, bodies etc.). Concretely, misogyny is manifested through religious beliefs, socioeconomic barriers, politics interdictions or boundaries and cultural practices, which represent women as dangerous, lower, defiled or dirty.

The interviewees were not asked by specific interrogations, but were all encouraged to report experiences and perceptions on topics such as family, their schooling processes, harassment, the option for a scientific career and situations of discrimination against women in academic context that they experienced or witnessed. Since it was a qualitative study, the chosen sample was intentional and non-probabilistic. The first contact was made by e-mail with coordinators of the Physics courses of both universities, explaining what the research was and looking for volunteers who could be interviewed. Thus, the technique used was the convenience sample, because a more thoughtful approach to select a sample was necessary (MARSHALL, 1996).

Below, there are excerpts from interviews that refer directly to these topics. Next, analyses about these female Physics professor's perceptions and experiences are made based on the education and gender literature field. The sections were segmented according to specific thematic axes: the devaluation of the teaching degree; posture, femininity and appearance within the classroom; moral harassment; gender differences and teaching-learning processes; and misogyny in Physics courses.

\section{The devaluation of the teaching degree}

Interviewees mention a recurrent macrosocial phenomenon in Brazil, pertinent to Physics as well as to teaching courses as a whole (SÁ; SANTOS, 2017): the devaluation - not only financial but also symbolic - of the teaching career, which is one of the reasons why this career became gender imbalanced in favor of women (PARAísO, 1997). It occurs especially when there is the option of a bachelor's degree in the same college. 
At times, there is no dialogue in many of these courses and they are almost independent among themselves (FIDALGO, 1996). The bachelor's degree in Brazil, especially in the public universities researched in this study, are more directed to the formation of researchers and scientists, whereas the teaching degree, mostly offered in the evening, is directed to the formation of teachers, with a strongly practical program and more superficial in what concerns scientific discussions, as showed by Vianna (2002). One first aspect for some interviewees is the existing idea that courses aimed to get a teaching degree are easier than the ones aimed to get a bachelor's degree:

Is the teaching degree seen as less prestigious?

"A little bit, yeah [...]" (Female Professor, 36 years old, married, one kid. Our translation).

And how do you see it, being the daughter of a Physics professor yourself?

"He got a teaching degree [...], at the time he chose it, the field of research wasn't that developed in Brazil [...]. I don't think it is less important, but I guess that the level of difficulty to conclude the course is lower [...]; back in his day, there was barely the idea of becoming a Physics researcher" (Female Professor, 36 years old, married, one kid. Our translation).

"[...] not because it's more or less important, but the teaching degree is actually easier than the bachelor's degree [...]" (Female Professor, 36 years old, married, one kid. Our translation).

The same interviewee pointed out another difference between a bachelor's degree and a teaching degree that, considering the matter of "being difficult/easy", favors the cleavage between the modalities: the teaching degree would allow an insertion in the job market immediately after the end of the course, which is not the same with the bachelor's degree. Thus, as found by Fidalgo (1996) and Svarcz (2017), the bachelor's degree would attract individuals from better social and financial conditions, whereas the teaching degree would generally be sought by those candidates who come from economically disadvantaged classes, since they require a faster entry into the labor market.

This is also bounded to their larger or smaller affinity with current values in the cultural elite. In the hierarchizing process of school contents, those considered more abstract and erudite, whose acquisition depends not only on competences linked to school study itself, but also on the social and cultural origin of students, are more valued, while the more practical and manual contents are quite overlooked. When Bourdieu and Passeron (2018) come to the French school system, for example, the sociologists show how the so-called talent disciplines (Philosophy, for example) are seen as superior to the so-called work disciplines (Nursery, for example). 
According to Therrien (1998), in the Brazilian university system, largely inherited from the French university structure, despite the influence it suffered from the American university organization during the dictatorial period (1964-1985), this can be seen, today, in the dichotomy between teaching degree, seen as a more "manual work" and "less talented degree" than the bachelor degree, which is also manifested by the speeches of the interviewees.

"[...] The teaching degree offers the opportunity of a job long before the bachelor's degree can do it; people who have a bachelor's degree can only have a formal job after they conclude their doctorate degree [...]" (Female Professor, 36 years old, married, one child. Our translation).

Compared to other occupations that demand a university degree, teaching offers little incentive in Brazil. The qualitative data indicate that, for some interviewed academics, teaching is a residual preference, chosen according to academic possibilities and to an immediate financial earning. Considering factors of refusal, the main cited was social and academic devaluation, which is confirmed by the literature, as instance, Cisne (2015) and Acker (1996).

The interviewees expressed crossness at the devaluation of the teaching course and the prejudice of colleagues. It is also evidenced by the interviewees that there is a current discourse in the institutions that states the teaching degree as associated to precarious working conditions, as postulates Brito (2019). The excerpt transcribed below reveals this social ideal in an exemplary way.

"[...] I took a bachelor's degree listening to people saying that undergraduate education was the worst thing in the world [...]. Nowadays, I want to sue these people [...], because they said that the degree did not help, it was those who did not know that they were going to do a degree, that the teacher did not earn anything [...], that there was no research [...]" (Female Professor, 49 years, married, one child. Our translation).

Based on Wagner, Acker and Mayuzumi (2008) and Brito (2019), we can say that this female professor discourse has to do with a broader context of the work at the universities nowadays, devaluating teaching classroom practices in order to value those dedicated to research and administration activities. Even those who value and enjoy teaching Physics in higher education, as it was the case of many of the interviewees, face the following contradiction: in order to be good professors, they must dedicate less to research and institutional administration (SVARCZ, 2017). Since resources and time are not enough for all activities - science, teaching, management and extension - they end up making choices, leaving certain activities aside or picking what to do first. 
Do you have a Bachelor's degree in Physics?

"I got a bachelor's degree for hearing people say that being a teacher and teaching were the worst things in the whole world [...]. Nowadays, I wanna sue those people..." (Female Professor, 49 years old, married, one child. Our translation).

Why is that?

"Because [they used to say] a teaching degree wasn't worth anything, only people who knew nothing would get it, teachers didn't earn any money [...], [they used to say] there wasn't any research" (Female Professor, 49 years old, married, one child. Our translation).

"I like teaching very much [...], I'm a teacher who likes to listen to the students, [...] on the first day of classes, I already schedule the exams [...], what's being left aside is the research, [...] and the administrative aspect takes up a lot of time [...]" (Female Professor from Argentina, 37 years old, married, no children. Our translation).

Teaching is not a field that draws the attention... I mean, attention from researchers, right?

"I didn't want to win the run for a position in Fundão [one of the campi of the Federal University of Rio de Janeiro] exactly for that reason, because I didn't want to waste my time teaching. I wanted to research. My dream was to pass the tests from CBPF [Brazilian Center for Research in Physics]. From the moment I got that position, I said: "Well, I'm being paid for that, so I'm gonna fight for the education to be better" [...]; I gave up my time in research to dedicate myself to teaching. What I believe is wrong is to consider that people who teach are not good researchers [...] science is elitist" (Female Professor from Argentina, 37 years old, married, no children. Our translation).

Finally, some of them noted that the Physics courses, especially the bachelor's degree and the strictu sensu post-graduation courses, fall short in what concerns to training teachers for higher education itself, because the focus of this degree in Brazil is research and the labor market (SVARCZ, 2017). This becomes evident when these scholars report that when they won the race for a professor position at the university, they were not sure about how to proceed in class with students, even though one of them had a major in teaching. The next professor discourse can be seen as a critique and an example of the less importance that teaching has in the formation of the future Physics professors, female and male, at and to universities (FREITAS, 2018).

"[...] So, during a subject I taught, I didn't know what to do in order to show the guys that a teaching degree can be something interesting [...]; so I thought: "Ok, I'm gonna tell them a story", [It was] a story about the formation of stars, about the Solar System... Then, I went on in the 
classroom: "Guys, in my son's class, I don't know if this is teaching, if it's methodology, what this is, but I do it, and the kids love it" [...] then, I fell in love with it in an impressive way [...], and when there's passion, that's all it takes for me..." (Female Professor, 49 years old, married, one child. Our translation).

Particularly considering the theme of teaching in higher education courses in Physics, literature in the area of teacher's training has already shown that many new students tend to repeat teaching models lived in their school trajectories, that is, they tend to act as their former teachers/professors (TEIXEIRA, 1998; GARG; AGRELLO, 2009). Therefore, it is important to rise up against patriarchal - as well as racist sexist and homophobic - logic, which still prevails in academic environments.

This aspect remains obscure for the area of higher education in Brazil, especially in the bachelor's degree, where the didactic subjects are still relegated to the College of Education and/or Psychology, practically ignored by professionals of other fields who are not obtaining a teaching degree, such as scientists. Thus, we end this topic with endorsements for a more vigorous handling of gender in research on women in higher education and in sciences, and mainly stressing the importance of training qualified teachers to graduate in Physics.

\section{APPEARANCE AND PERSONAL POSTURE IN THE CLASSROOM}

It was often heard in our study that a female professor has to dress soberly, less feminine, in order to avoid harassment and comments by male students. This can be interpreted as a tacit requirement to deny the specificity of female bodies as proof of competence, not only in laboratories and field practices, but also in the classroom. Acker (1996), for example, argues that this is because the defeminized body would not attract male gaze and desire, a psycho-cultural process that shows a curious fact about society, because instead of educating (socializing) male academics (both students and professors) to be respectful to the few women who circulate there, which is not reported in any of the speeches, women are the ones who must hide and conceal their femininity to avoid the natural male desire.

\section{[...] Do you take any precaution before going to the classroom?}

"Yes, I do [...]; regarding the clothes I wear [...]; normally, I wear clothes that are not too "girly" (Female Professor, 36 years old, married, one child. Our translation).

Do the clothes, somehow, communicate something? Do they give you respectability? [...] What if you wear a dress, show some cleavage...

"Then, I may draw more attention because there are less women there [...]. I think it doesn't matter, but, unfortunately, some people treat you differently (Female Professor, 35 years old, married, no children. Our translation). 
A professor mentioned that she has not been directly distraught, but she remembers jokes by a male student and, especially, comments and glances of sexual desire by male colleagues towards the female professors when she was a student herself. It indicates that the target/concern of the male students in the aforementioned cases was not about the intellectual or didactic attributes of the professional, but about the physical attributes, a clear example of how the macho culture objectifies women (RISTOFF, 2006).

Have you ever been harassed... by a male student?

"Not exactly harassed, but I've heard some flirtatious jokes... [...] I don't remember it very clearly, but I do remember what I thought: "I can't be too relaxed about this student's attitude, or it may get worse..." [...]. It wasn't something in relation to being a woman. [...] I also remember some colleagues talking about the female professors, that's a memory I have, if the professor was a beautiful woman, the male students would sit in the first row to wait for her to cross her legs... That I remember very well" (Female Professor, 36 years old, married, one child. Our translation).

Traditionally, in academic context, ideas of professionalism and competence are related to a man image. Therefore, many women have learned that to 'dress like a man' can help them to divert attention to their sex condition. In this way, a manner to mitigate this would be to divulge images of success women in science in order to transform the collective thought that outlines women as emotional only and whose "nature" is taking care of others. Furthermore, in a gender perspective, it is also necessary to show that being ingenious or having careful temperament are historic and cultural constructions.

\section{MORAL AND SEXUAL HARASSMENT}

One of the interviewees said she felt intimidated and humiliated by a male professor. Then, she found encouragement and support to continue the course in one of her female professor's perseverance story when she was in graduate school. It indicates one of the pillars that has been defended in the broader study (FREITAS, 2018): the importance of having more women - professors, researchers, heads of departments - in the Physics and Exact Sciences courses, so that it can not only allow formal alliances, but also positively affect the psyche of male students and especially of female students, showing that it is also possible for them to ascend in the career (GARG; AGRELLO, 2009).

What one of her professors did to some students, those who were more timid and insecure, is what we can call the typical bullying, which is a form of verbal and/or psychological violence from someone who considers himself/herself (or is considered) stronger than those who are psychologically fragile and/or who are in a social position considered inferior (SÁ; SANTOS, 2017). 
Embarrassing situations... have you ever experienced any?

"In my class, there were more women than usual [...], then we were taken by surprise [...]. The assistant of one of the professors was awful, he used to rub up against us..." (Female Professor, 49 years old, married, one child. Our translation).

And nobody reacted?

"Not really [...], I didn't know what to do [...], I was there, completely lost, with that professor who yelled at me [...]. If I wrote a report, he would say it was wrong, that it was a horrible report, that I didn't know how to do anything" (Female Professor, 49 years old, married, one child. Our translation).

Did he have the same attitude towards any student?

"Towards some students [...], they were shyer people, more insecure. If you demonstrated a little more attitude, if you faced him, it was a little different [...]. I had the feeling of giving up, completely [...], I had that shock. Then, at a certain point, I had a Calculus professor, Math actually, she was fantastic [...], she used to work in Stiletto heels, she used do wear her hair in a bun, she wasn't a pretty woman, but she would "stand out", you know? She would brighten the room... [...] and, then, that woman started to talk about her difficulties, her story, and she would raise interesting points like "do you think it was easy for Isadora Duncan to dance for the first time?" That gave me some sort of support [...]" (Female Professor, 49 years old, married, one child. Our translation).

According to the literature (PARAÍSO, 1997; NASCIMENTO; PLANTIN; VIEIRA, 2008; SÁ; SANTOS, 2017) these occurrences negatively interfere in the classroom routine, for instance: although not intentionally, female teachers are more frequently questioned about the attribution of grades, or female students are ridiculed and/or silenced by man colleagues when they ask some questions.

\section{GENDER AND TEACHING-LEARNING ISSUES}

Analyzing the discourses, it is noticed that for some interviewees, female students present behaviors that are more typically valued by school institutions, such as being more careful, obedient and cordial. However, on the other side, male students are seen as bolder and more independent in what concerns learning, as well as some female students present more passive and hesitant behavior. This phenomenon, present in our society, is not related to the physiological issues of gender differences, as it is generally approached, but rather to the way in which girls and boys are socialized in the familiar environment and, especially, at school, from the earliest childhood (RISTOFF, 2006). 
It is also observed that many of the characteristics attributed to male and female students are perceived by the interviewees at different levels of education - from elementary school even up to the master's degree -which points to greater female dedication to studies compared to boys and shyness of female students in contrast to male students.

Do you think there's any different behavior between men and women in these courses?

"Women are always more organized, they write way better and more, they don't 'lose' any information, it's the same you see during elementary and high school" (Female Professor, 37 years old, married, no children, from Argentina. Our translation).

Do you see behavioral differences between male and female students in the classroom? Do you notice differences in their reactions or even specific difficulties?

"I think female students are more timid, they seem to be jumpier from the beginning, just as I was in the beginning too, so I see that some students enter the Master's, you know these girls [...]. They don't have that toughness yet. Then I talk to them, they learn from me, they have to be strict [...]. You enter the Physics area with that preconceived idea that only men know Physics... So you start with this vision that there are only men there (Female Professor, 40 years old, single, no children. Our translation).

The following extract reveals a pattern among the 11 female interviewees: all of them were seen and used to see themselves as very good, and some of them, even brilliant throughout school and their academic life.

"Some women report they've had negative experiences in the Physics course... [...].

I've never had a problem [...]. I was one of the best of the course when I graduated [...], there were seventy people in my class in the beginning of the course, ten were women" (Female Professor, 35 years old, married, no children. Our translation).

\section{MISOGYNY IN PHYSICS}

The interest and insertion of women and men in any area of knowledge have been identified as the result of socialization initiated and reinforced since the early years of life in the family, by the media, religion, school, finally, in many environments of collective interaction (BLACKMORE; SACHS, 1997). In this sense, and as sustained by Garg and Agrello (2009), in our research, almost all female interviewees were unanimous in considering that the Physics area is somewhat hostile to the female sex. Similar veiled hostility has also been seen in other professional fields, by Lombardi (2017), for example, in Engineering. Some of them, as 
explained below, are impelled to develop attitudes and behaviors considered strict, perhaps being seen as so because they were women.

Maybe, if male professors behaved the same way, it would be seen as normal, since assertiveness ("I am really strict") and warmongering ("I'm going to fight") are culturally associated to the male gender in our society (BLACKMORE; SACHS, 1997). Such behaviors would, in fact, be strategies for organizational survival: in relation to colleagues and even to daring students, from whom they try to avoid harassment. Thus, many female professors claim to have to adopt more aggressive and unfriendly stances in order to be respected.

It can also be inferred that the dilemma posed by society for the woman who decides to pursue an academic career opposed to a family life, children (or not having them) or even getting married (or not), is a form of symbolic violence, one of the effects of the misogyny that has permeated the western capitalist culture for centuries (SUMMERS, 2013).That can be said considering that such a dichotomy, that is, opting and/or having to be divided between private life and a promising scientific career, rarely applies to men (GARG; AGRELLO, 2009).

As Teixeira, Nascimento and Villani (2008) and Svarcz (2017) point out, male scientists, in general, are able to coexist with a personal and professional life without big problems; on the other hand, as described by our interviewee, female scientists report family as an element of stress, conflicts or professional impediment.

How do you deal with it?

"People here say I'm strict, because I really am strict so they can't get on top of me, 'cause here there are many men [...); I always hear them say that there's no women who are good at Physics, then, I believe this department is misogynous, but I don't get intimidated.

If I wanna do something, I'll do it no matter what they think... So I'm gonna fight" (Female Professor, 40 years old, single, no children. Our translation).

You said that, in a way, you gave up your personal life...

"In fact, I did [...], actually, my career's been my priority, I came back from Europe [from France, split-site PhD program] and I said: I want to work at a Federal University; since the beginning, my dream was to work here as a professor... [...]. I planned it. I worked hard [...], sometimes I would go home at 3 a.m." (Female Professor, 40 years old, single, no children. Our translation).

Lastly, a female researcher believes that there have been changes for the better since the time she was a student in comparison to the present time in the Physics course, as far as being a woman is concerned (TEIXEIRA; NASCIMENTO; VILLANI, 2008). She also observes that the number of women in this field has been increasing: 
Would you like to comment on any aspect we've covered during the interview or is there any topic you'd like to raise?

"[...] the number of women in the Physics course is increasing, so I guess that it comes from the interest of people in the topic, I think the field is, in fact, more open than it used to be before, maybe it was worse in the past than it is nowadays" (Female Professor, 40 years old, single, no children. Our translation).

Freitas (2018) shows that the absolute and percentage numbers of postgraduate and undergraduate students in Physics has been increasing over time at UFMG. In spite of this, the higher researcher positions of the National Council for Scientific and Technological Development (CNPq) and the senior professors chairs, which represent the highest level of the university career, are still mostly occupied by men. This reality can also be seen in other teaching and research institutions in Brazil (SVARCZ, 2017), showing that women are still faced with a conjunction of cultural, political, economic and symbolic factors that obstruct and/or hinders them to ascend in the academic career, especially in the field of nominated hard sciences.

\section{CONCLUSION}

Brazilian society is still marked by beliefs about the nature of the sexes dividing spaces, interests and actions. In teaching, these beliefs also gain strength, being confirmed in the relationships established among individuals, in teaching methodologies, in a false sense of vocation, disregarding cultural aspects, individual interests and in many institutional routines and practices. The discussion surrounding women, teaching work and feminization is a widespread issue that has ranged from the reason why the teaching career became gender imbalanced in favor of women to the impacts that this might have on learning processes results.

The social and cultural differences between sexes show that there are feminine and masculine meanings connected with the teacher's role and with school relationships; they also indicate an articulation between sex and gender in higher education teaching. Such a process sustains a misperception that success and failure are simply the result of individual skills or deficiencies. Therefore, it is not enough to guarantee women's access to higher education, it is necessary to establish stronger policies on structural and cultural changes within organizations and change their micropolitics. In this study, the importance of support among women is observed, either for the development of studies or to sustain the career as teachers and researchers.

Resisting and confronting these exclusionary dynamics is not simple for women, as many of them do not even realize that they are excluded or curtailed in the academy because of 
gender issues. The difficulties throughout the academic trajectory are not only a matter of merit, they also express social structures of power and prejudice that are culturally rooted, in this case, the strategies of exclusion and discrimination against women in Physics teaching careers. Therefore, the called absolute academic neutrality, defended by Positivist Philosophy, does not exist; it is crossed by gender, race, class and others social markers.

Concerning precisely the moral harassment and abuse, we saw that there is a certain inertia in Physics academic area about it, a kind of silence and naturalization. From a feminist point of view, some actions to guide new students to face these situations, not only in Physics, but in STEM ${ }^{7}$ areas in general, would be: 1 - to stimulate the sorority; 2 - to create a network among victims for mutual support and reporting abuse; 3 - to promote discussion groups and optative lectures about misogyny and gender inequality to support the identification of imperceptible discriminations; 4- to do conferences to freshman students where the university's police against discrimination is announced as well as sanctions against those who break this code, among others pedagogic actions.

\section{REFERENCES}

ACKER, Sandra. Gender and teacher's work. Review of Research in Education, v. 2, n. 1, p. 99162, 1996.

BALL, Stephen. La micropolitica de la escuela: hacia una teoría de la organización escolar. Barcelona: Paidós, 1989.

BARRETO, Andreia. A mulher no ensino superior. Distribuição e representatividade. Cadernos do GEA, n. 6. Rio de Janeiro: FLACSO/UERJ/LPP, jul./dez. 2014.

BENÍCIO, Ronildo Alves. Uncertain future for women scientists in Brazil. Nature, v. 567, n. 7747, p. 31-32, 2019.

BLACKMORE, Jill; SACHS, Judyth. Worried, weary and just plain worn out: gender, restrutucturing and the psychic economy of higher education. In: ANNUAL CONFERENCE, $n$. 1-4, 1997. Brisbane. Anais [...] Brisbane: AARE, 1997.

BOURDIEU, Pierre; PASSERON, Jean-Claude. Os herdeiros: os estudantes e a cultura. 2. ed. Florianópolis: Editora UFSC, 2018.

BRITO, Thiago. Trabalho, docência e precarização: breves notas de um projeto de pesquisa. Trabalho \& Educação, Belo Horizonte, v. 28, n. 3, p. 161-178, 2019. Disponível em: https://periodicos.ufmg.br/index.php/trabedu/article/view/9844. Acesso em: 6 jan. 2021. DOI: https://doi.org/10.17648/2238-037X-trabedu-v28n3-9844.

\footnotetext{
${ }^{7}$ Science, Technology, Engineering and Mathematics.
} 
CARABINE, Jean. Unmarried motherhood 1830-\1990: A genealogical analysis. In: WETHERELL, Margaret; TAYLOR, Stephanie; YATES, Simeon. J. (ed.). Discourse as Data: A Guide for Analysis. London: Sage, 2001.

CISNE, Mirla. Gênero, divisão sexual do trabalho e serviço social. 2 ed. São Paulo: Outras Expressões, 2015.

FIDALGO, Fernando S. O. Trabalho e carreira docente: contribuições teórico-metodológicas, Trabalho e Educação, Belo Horizonte, n. 0, p. 94-109, jul./dez. 1996.

FREITAS, Marcel de A. Mulheres Cientistas. Percursos e percalços a partir da realidade da UFMG. Belo Horizonte: Conhecimento, 2018.

GARG, Reva; AGRELLO, Deise A. Mulheres na Física: poder e preconceito nos países em desenvolvimento, Revista Brasileira de Ensino de Física, São Paulo, v. 31, n. 1, p. 1301-1306, 2009.

INSTITUTO NACIONAL DE ESTUDOS E PESQUISAS EDUCACIONAIS ANÍSIO TEIXEIRA (INEP). Trajetória da Mulher na Educação Superior Brasileira - período de 1991 a 2004. Brasília: MEC, 2005.

LETA, Jacqueline. Mulheres na ciência brasileira: desempenho inferior? Revista Feminismos, Salvador, v.2, n. 3, p. 139-152, 2014. Disponível

em: https://cienciasmedicasbiologicas.ufba.br/index.php/feminismos/article/viewFile/30039 /17771. Acesso em: 26 ago. 2016.

LOMBARDI, Maria Rosa. Engenheiras na construção civil: a feminização possível e a discriminação de gênero. Cadernos de Pesquisa, São Paulo, v. 47, n. 163, p.122-146, 2017.

MARSHALL, Martin N. Sampling for qualitative research. Family Practice Review, v. 13, n. 6, p. 522-525, 1996.

MELO, Hildete P.; LASTRES, Helena M. M.; MARQUES, Teresa C. M. Gênero no Sistema de Ciência, Tecnologia e Inovação no Brasil. Revista Gênero, Niterói, v. 4, n. 2, p. 73-94, 2004.

MIRANDA, Teresa, L.; SCHIMANSKI, Edina. Relações de gênero: algumas considerações conceituais. In: FERREIRA, Aparecida De Jesus (org.). Relações étnico-raciais, de gênero e sexualidade: perspectivas contemporâneas. Ponta Grossa: Editora UEPG, 2014.

NASCIMENTO, Silvânia S; PLANTIN, Christian; VIEIRA, Rodrigo D. A validação de argumentos em sala de aula: um exemplo a partir da formação inicial de professores de Física, Revista Investigações de Ensino de Ciências da UFRS, Porto Alegre, v. 13, n. 2, p. 68-185, 2008.

PARAÍSO, Marlucy A. Gênero na formação do/a professor/a: campo de silêncio do currículo? Cadernos de Pesquisa (Fundação Carlos Chagas), São Paulo, v. 1, n. 102, p. 23-45, 1997. 
RISTOFF, Dilvo. A trajetória da mulher brasileira na educação. Folha de São Paulo, São Paulo, 8 mar. 2006. Disponível em: https://www1.folha.uol.com.br/fsp/opiniao/fz0803200610.htm Acesso em: 23 maio 2016.

SÁ, Carmen S. S.; SANTOS, Wildson L. Constituição de identidades em um curso de licenciatura em Química. Revista Brasileira de Educação, Rio de Janeiro, v. 22, n. 69, p. 315338, 2017.

SCOTT, Joan. Os usos e abusos do gênero. Projeto História, São Paulo, n. 45, p. 327-351, dez. 2012.

SUMMERS, Anne. The misogyny factor. Sydney: New South Wales University, 2013.

SVARCZ, Kariane C. Relações de Gênero na Física: a inserção das mulheres na "ciência hard" da UFSC (1980-2010). Dissertação (Mestrado em História) - Universidade do Estado de Santa Catarina, Florianópolis, 2017.

TEIXEIRA, Adla B. M. The Domestication of primary school teaching: a Brazilian study case. 1998. Thesis (Doctorate in Education) - Institute of Education, University of London, London, 1998.

TEIXEIRA, Adla B. M.; NASCIMENTO, Silvânia S.; VILLANI, Carlos E. Exploring Modes of Communication among Pupils in Brazil. Gender and Education, v. 20, n. 4, p. 387-398, jul. 2008.

THERRIEN, Ângela T. S. Trabalho docente: uma incursão no imaginário social brasileiro. São Paulo: EDUC, 1998.

VIANNA, Cláudia. O sexo e o gênero da docência. Cadernos Pagu, Campinas, n. 18, p. 81-103, 2002.

WAGNER, Anne; ACKER, Sandra; MAYUZUMI, Kimine. Whose university is it anyway? Toronto: Sumach Press, 2008. 


\section{Marcel de Almeida Freitas}

Sociólogo (UFMG), licenciado em Sociologia (UFMG), mestre em Psicologia Social (FAFICH/UFMG), Doutor em Educação (FaE/UFMG) e professor adjunto na Universidade do Estado de Minas Gerais, onde ministra disciplinas como Filosofia, Antropologia e Sociologia. Temáticas de atuação: Sociologia e Antropologia da Educação, relações de gênero. Integra o Grupo de Estudos em Gênero e Sexualidade na Educação (GSS/FaE/UFMG).

marcel.fae.ufmg@gmail.com

\section{Adla Betsaida Martins Teixeira}

Pedagoga e mestre em Educação Internacional Comparada pela University of London, doutora em Cultura, Educação e Comunicação pela University of London, pós-doutora em Gênero e Direitos Humanos pela Université de Lyon, pós-doutora em Aprendizagem e Ensino Superior pela Stanford University, professora associada IV da Faculdade de Educação da Universidade Federal de Minas Gerais (FaE-UFMG) e coordenadora do Grupo de Estudos em Gênero e Sexualidade na Educação (GSS/FaE/UFMG). Temáticas de atuação: didática, gênero e educação, mulheres nas ciências.

adlaufmg@gmail.com

\section{Denise Bianca Maduro Silva}

Pedagoga pela Universidade Federal de Minas Gerais e mestre em Ciências Sociais pela Facultad Latinoamericana de Ciencias Sociales (FLACSO-Argentina). Apresenta doutorado em Educação pela Faculdade de Educação da Universidade Federal de Minas Gerais (FaE-UFMG) e doutorado latino-americano em Educação. Técnica em Assuntos Educacionais na Pró-Reitoria de Extensão da UFMG desde 2009. Temáticas de atuação: avaliação de políticas públicas, educação comparada, extensão universitária, educação profissional e educação integral.

denisebianca@reitoria.ufmg.br 